\title{
Multivariate analysis of experimental marine ecosystems
}

\author{
C. A. Oviatt ${ }^{1}$, K. T. Perez ${ }^{2} \&$ S. W. Nixon ${ }^{1}$ \\ 1 Graduate School of Oceanography, \\ University of Rhode Island; Kingston, Rbode Island, US A, \\ and \\ 2 Environmental Research Laboratory, \\ U.S. Environmental Protection Agency; Narragansett, Rbode Island, USA
}

\begin{abstract}
Twelve replicate 150-1 laboratory microcosms were developed using whole water samples and natural benthic communities from Narragansett Bay, Rhode Island (USA). The microcosms were scaled to the bay in terms of salinity, temperature, light input, volume pelagic community to area of benthic community, density of macrofauna, turbulent mixing, and flushing time. The microcosms were self maintaining during a six month study period with over 35 species of phytoplankton and 30 species of macro-invertebrates. Some 25 species of meroplankton entered the microcosms and successfully colonized the benthic communities. Zooplankton were present in all life stages. After an initial study of replication among the 12 tanks, the microcosms were perturbed with 3 levels of treated urban sewage for a three month period. Three microcosms were maintained at each level with 3 tanks remaining as controls. At the end of 3 months, the sewage input was terminated and the response of the systems was followed for an additional 2 months. Both time series data and multivariate statistical analysis of over 10 different parameters indicated that the replication of the microcosms was adequate to show the effects of experimental treatments. Control microcosms were generally within the range of variation expected in Narragansett Bay. Moreover, the results suggested that the microcosms responded to the gradient of sewage input in a manner similar to that of the bay. During the two month period after the sewage was discontinued, all of the microcosms became increasingly similar, though the tanks that had been subjected to higher levels of sewage remained distinct. It was apparent throughout the study that comparisons of microcosms and natural systems must account for the large variation characteristic of each. For this, and other reasons, multivariate statistical techniques appear to provide a powerful tool for experimental ecosystem analysis.
\end{abstract}

\section{INTRODUCTION}

\section{Ecosystem analysis - holism and reductionism}

An interesting dilemma faces anyone trying to do ecosystem level research, whether it is in the marine environment or elsewhere. On one hand, there is a general acceptance that the holistic principle applies to living systems (von Bertalanffy, 1968), and that natural communities are more, or at least something other than the sum of their parts (Odum, 1971; Patten, 1971; Mann, 1972, 1975). If so, the data 
gathered by traditional reductionist methods may not be very helpful in making predictive statements about the behavior of complex marine ecosystem or their probable response to perturbations of various kinds. On the other hand, natural ecosystems are usually large, unreplicated, without environmental control, and therefore protected to some degree from tampering by well meaning researchers. While it has occasionally been possible to overcome these problems in doing experimental ecosystem work on land (e. g. Likens et al., 1970; Odum, 1970), it has seldom been practical with natural marine ecosystems. As a result, our knowledge of marine ecology has developed in bits and pieces from many individual studies of the behavior and dynamics of phytoplankton, zooplankton, etc. We can only hope that the best data base that has evolved under this reductionist approach can be synthesized in some useful way through the mechanistic modeling projects now underway (Steele, 1974; Walsh, 1975; Kremer \& Nixon, 1975; and numerous others).

\section{The microcosm method}

In seeking a way to carry out practical yet holistic ecosystem research, a number of workers have used small-scale living models or microcosms of larger natural systems that can be maintained and manipulated in the laboratory. The rationale and potential of the microcosm approach in general have been described by Beyers (1963) and Cooke (1971), and with specific reference to coastal marine waters by Abbott (1966). A review of the use of multi-species cultures and microcosms, especially in the marine environment, has been prepared by Levandowsky (in press). At the present time, at least five major marine microcosm studies are underway, including projects at Kiel Bay, Germany (von Bodungen et al., 1976; Smetacek et al., 1976), at Loch Ewe, Scotland (Davies et al., 1973), at Narragansett Bay, Rhode Island (Knauss et al., 1976), at Sanich Inlet, British Columbia (Takahashi et al., 1975), and at Kaneoke Bay, Hawaii (S. V. Smith, personal communication). In spite of the impressive efforts involved in these, and other microcosm studies, the methodology of microcosms (or, in some cases, mesocosms) is still evolving. For example, it is far from clear how microcosms may best be scaled to the "real world" in terms of energy inputs for biological production and physical mixing or what the effects of larger animal exclusion may be. There is also the possibility of serious artifacts from the lack of spatial heterogeneity and small size in microcosms, as well as from the "wall effects" of high surface to volume ratios characteristic of enclosed communities. As with numerical simulation models, there appears to be no generally agreed upon criteria for evaluating the credibility of living models or for comparing the behavior of microcosms with the "real" systems they represent. In a sense, microcosm research is still an iterative process in which methodological and conceptual problems of experimental design are as much a part of the study as data collection and analysis.

With these limitations and challanges in mind, however, the microcosm approach may yet prove to be a powerful tool for marine ecosystem research and management. This paper reports results from the first in a series of perturbation and recovery experiments using microcosms designed as analogs of Narragansett Bay, Rhode Island. 
The experiments were designed to examine the replicability of marine microcosms, to compare the behavior of the microcosms with that of a natural marine bay, and to evaluate the use of the microcosms as a tool for studying the larger system.

\section{METHODS}

\section{Design of the microcosms}

A laboratory microcosm facility was designed to accommodate 12 plastic tanks in a flow through water bath under controlled conditions of temperature, salinity, light, flushing, physical mixing, and material input (Perez et al., 1976). During the experiment described here, an attempt was made to approximate the environmental conditions of Narragansett Bay (Table 1).

Narragansett Bay is a plankton based temperate estuary in southern New England (Fig. 1). It a well mixed system with relatively small fresh water inflow,

Table 1

Characteristics of Narragansett Bay microcosms

\begin{tabular}{|c|c|}
\hline Volume & 1501 \\
\hline Depth & $0.70 \mathrm{~m}$ \\
\hline Turnover time & 37 days (similar to lower Narragansett Bay, U.S.A.C.E. 1959) \\
\hline Source of input water & $\begin{array}{l}\text { Surface whole water samples from the lower West Passage of } \\
\text { Narragansett Bay (Fig. 1) }\end{array}$ \\
\hline Salinity & $24 \% 0-31.5 \%$ \\
\hline Temperature & $\begin{array}{l}\text { 6.5 C-24.2 C (maintained in a water bath to } \pm 1.5 \mathrm{C} \text { Narra- } \\
\text { gansett Bay) }\end{array}$ \\
\hline Photoperiod & 9 to 16 hours (adjusted monthly to match the natural system) \\
\hline Light energy* & $21.5-31.0 \mathrm{ly} /$ day \\
\hline Relative turbulence & $\begin{array}{l}\text { The microcosms were stirred with } 0.14 \mathrm{~m}^{2}, 1.8 \mathrm{~cm} \text { plastic mesh } \\
\text { paddles at } 32 \mathrm{rpm} \text {. The paddles were rotated for } 30 \text { sec., then } \\
\text { stopped for } 6 \mathrm{sec} \text {, then reversed for } 30 \text { sec. in a continuous } \\
\text { cycle. The dissolving rate of hard crystalline sugar balls, our } \\
\text { measure of relative turbulence, was }-0.150 \mathrm{~g} / \mathrm{min}(\sigma=1.005 \text {, }(\sigma=1.00 \mathrm{~g} / \mathrm{min}(\sigma= \\
\mathrm{N}=5) \text { in the microcosms compared with }-0.174 \mathrm{~g} / \mathrm{m} \text {, } \\
0.004, \mathrm{~N}=6) \text { in the bay }\end{array}$ \\
\hline Area of sediment & $\begin{array}{l}167 \mathrm{~cm}^{2} \text {. Maintained in opaque box cores immersed in each } \\
\text { microcosm. A vacuum pump system flowed microcosm water } \\
\text { over the benthic community at } 0.73 \mathrm{I} / \mathrm{min} \text {, a flow fast enough } \\
\text { to prevent the } \mathrm{O}_{2} \text { concentration over the benthos from dropping } \\
\text { by more than } 0.1 \mathrm{mg} / 1\end{array}$ \\
\hline \multicolumn{2}{|c|}{$\begin{array}{l}\text { * At surface of the tanks. Calculations of light intensity at mid-depth in the lower West } \\
\text { Passage of Narragansett Bay during this period ranged from } 14.2-21.1 \text { ly/day }(\mathrm{z}=5 \mathrm{~m} \text {, } \\
\left.\mathrm{K}=0.55 \mathrm{~m}^{-1} \text {, surface light from Epply Laboratories, Newport, } \mathrm{RI}\right) \text { A mixture of high } \\
\text { intensity fluorescent and incandescent bulbs was used to give a spectral composition similar } \\
\text { to that found at mid-depth in the bay. }\end{array}$} \\
\hline
\end{tabular}


generally high salinity $(>20 \%)$ and little vertical stratification. The average depth is about $10 \mathrm{~m}$. While there is little organic input to the bay from marshes or macrophytes, there is a clear eutrophication gradient from north to south that results from large inputs of primary and secondary sewage in the upper bay (Fig. 1). In general, however, the water quality at the location of the laboratory in the lower bay is excellent.

\section{Experimental design}

The 12 microcosms were filled in mid March, 1975, using hand bucketed water samples (to prevent damage to plankton) collected over a 6 hour flood tide from the surface of the lower West Passage of the bay (Fig. 1). For the next 7 days, the microcosms were throughly intermixed to insure a uniform distribution among the tanks. A heterotrophic benthic community was included in each microcosm in a flow

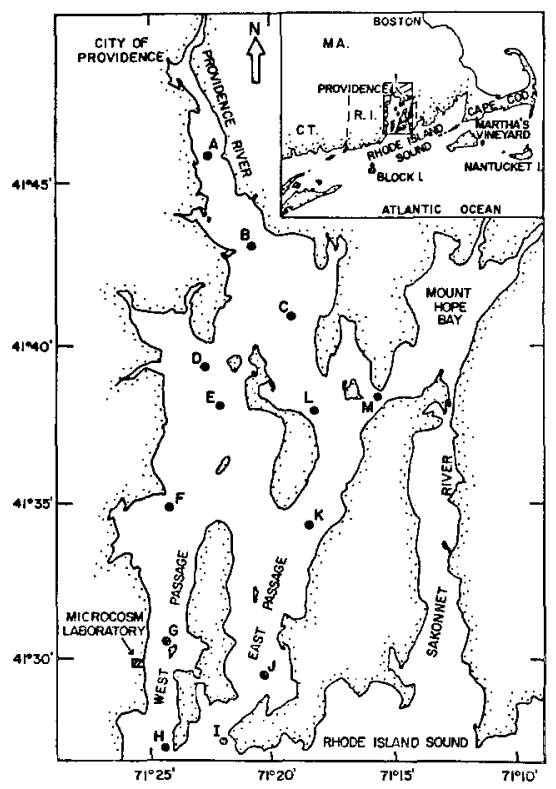

Fig. 1: Location of the microcosm laboratory on the lower West Passage of Narragansett Bay, Rhode Island (USA). The lettered stations were used to collect field data on the spatial variability of plankton and nutrients in the bay over an annual cycle in 1971-1972

through (vacuum pump) dark box immersed in the tank (Perez et al., 1976). The community used in the work discussed here was collected near the middle of Narragansett Bay in an area with unpolluted silt-clay sediments dominated numerically by the bivalve $N$ ucula annulata. The sediments were screened $(0.75 \mathrm{~mm})$ to separate the macrofauna, which were then placed in equal numbers in each benthic box. Material scrubbed from the sides of the plastic tanks and collected on the bottom during cleaning was added to the benthos three times a week. 
After the intermixing period, all 12 of the microcosms were monitored for 15 days to determine the replication of the systems. The parameters measured and methods used during this period and throughout the study are summarized in Table 2. At the end of this period, 9 of the microcosms were perturbed with 3 different levels of treated urban sewage collected from the largest treatment plant on the Providence River (Fig. 1).

\section{Sewage in puts}

Since one of the objectives of this study was to see if the behavior of the microcosms approximated that of the larger natural system, it seemed appropriate to find

Table 2

Summary of the analytical methods and sampling procedures used in this study to characterize the Narragansett Bay microcosms

\begin{tabular}{|c|c|c|}
\hline Parameters & Frequency & Method \\
\hline $\begin{array}{l}\text { Nutrients: } \\
\text { ammonia }\end{array}$ & 2/week & Solorzano (1969) \\
\hline nitrite \& nitrate & 1/week & Technicon Autoanalyzer \\
\hline phosphate & $1 /$ week & Strickland \& Parsons (1968) \\
\hline $\begin{array}{l}\text { dissolved organic } \\
\text { phosphorus }\end{array}$ & 1/week & Menzel \& Corwin (1965) \\
\hline $\begin{array}{l}\text { Plankton: } \\
\text { chlorophyll a }\end{array}$ & $2 /$ week & $\begin{array}{l}\text { Extracted flourescence calibrated with spectro- } \\
\text { photometric determinations of extracted pigment } \\
\text { (Strickland \& Parsons, 1968) }\end{array}$ \\
\hline ATP & $2 /$ week & Integrating photometer (Cheer et al., 1974) \\
\hline $\begin{array}{l}\text { Particle size } \\
\text { frequency }(0-50 \mu)\end{array}$ & $2 /$ week & $\begin{array}{l}\text { Curby Assay System based on the Coulter prin- } \\
\text { cipal }\end{array}$ \\
\hline Phytoplankton & $1 /$ week & $\begin{array}{l}\text { Cell counts and species identification on samples } \\
\text { preserved in Lugol's solution }\end{array}$ \\
\hline Zooplankton & $1 /$ month & $\begin{array}{l}\text { Identification of major groups and counts of rel- } \\
\text { ative abundance in } 1 \text { liter samples }\end{array}$ \\
\hline $\begin{array}{l}\text { Benthos: } \\
\text { macrofauna } \\
\quad(>0.75 \mathrm{~mm})\end{array}$ & $\begin{array}{l}\text { initial \& } \\
\text { final samples }\end{array}$ & $\begin{array}{l}\text { Identified, counted, and placed in equal numbers } \\
\text { in each benthic box at the beginning of the ex- } \\
\text { periment. On termination, each box was sieved } \\
(0.5 \mathrm{~mm}) \text { and all animals were identified, } \\
\text { counted, and weighed }\end{array}$ \\
\hline $\begin{array}{l}\text { meiofauna } \\
\text { nematodes and } \\
\text { ciliates }\end{array}$ & $\begin{array}{l}\text { one sample } \\
\text { only at end } \\
\text { of sewage } \\
\text { addition }\end{array}$ & $\begin{array}{l}\text { Successive washings through } 80 \mu \mathrm{m} \text { screen with } \\
\text { mechanical disruption of detrital lumps using a } \\
\text { needle and } 12 \times \text { dissecting scope. Animals were } \\
\text { pipetted onto a grid, counted, and major groups } \\
\text { identified }\end{array}$ \\
\hline $\begin{array}{l}\text { sediment } \mathrm{CHN} \\
\text { analysis }\end{array}$ & $\begin{array}{l}\text { final sample } \\
\text { only }\end{array}$ & Analyzer Model 1100, Carlo Erba \\
\hline
\end{tabular}


out if the microcosms which resembled the "clean" lower West Passage of the bay would develop the characteristics of the more eutrophic upper regions of Narragansett Bay when they were exposed to a sewage gradient similar to that found in the natural system. Initially large quantities (41,101 and 201) of sewage were added to tripli-

Table 3

Composition of the treated urban sewage added to the Narragansett Bay microcosms

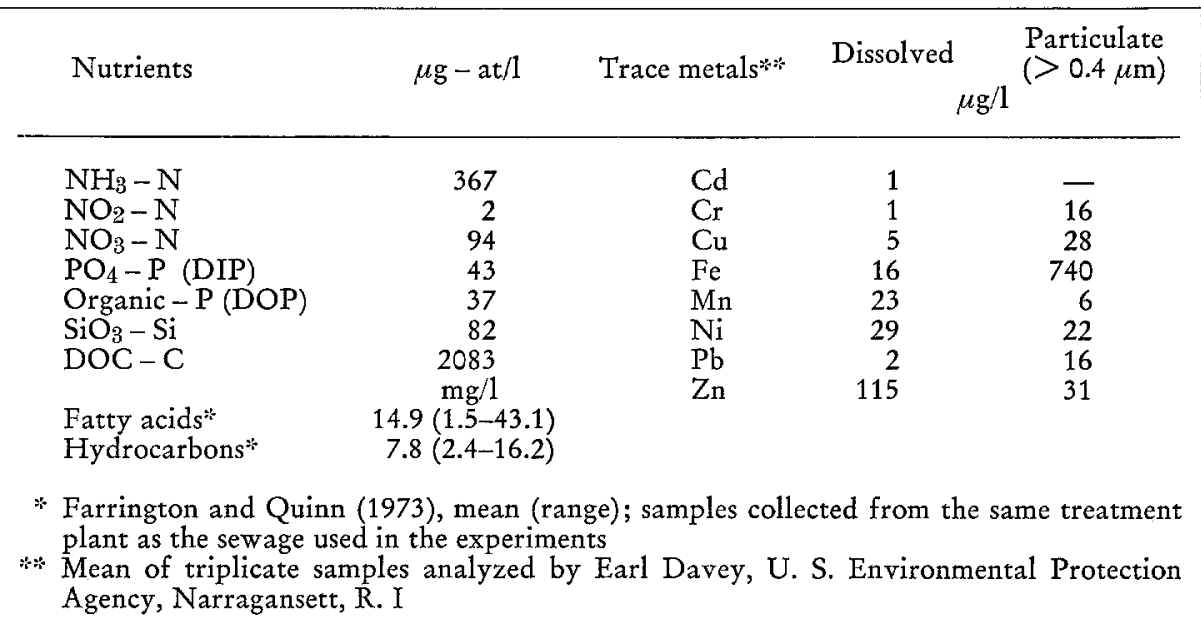

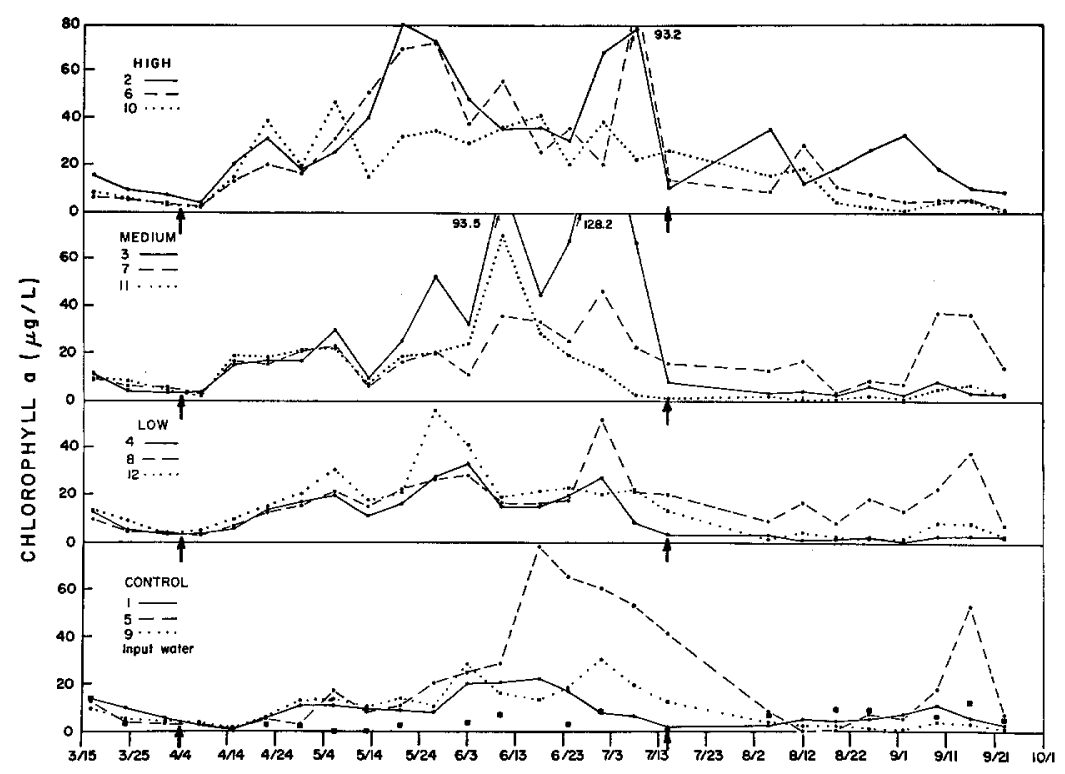

Fig. 2: Pelagic chlorophyll $a$ in the experimental microcosms. Arrows indicate the beginning and the end of the sewage addition 
cate microcosms to simulate an ammonia gradient from a sewage outfall of 10,25 and $50 \mu \mathrm{g}$ at N/1. The Providence River which has ammonia concentrations as high as $31 \mu \mathrm{g}$ at $\mathrm{N} / 1(\overline{\mathrm{x}}=14, \mathrm{~N}=52)$ and which receives $0.3 \%$ sewage by volume per day provided the basis for choosing this gradient and a logarithmic series $(0,0.01,0.1$ and $1.0 \%)$ of sewage by volume for new input water added three times a week. Even though the sewage addition caused only a small decrease in salinity $(4.0 \%$ ), fresh water was added proportionally to the lower sewage dose tanks to make the change constant for all treatments. The sewage for the entire experiment was collected at one time, analyzed (Table 3), separated into aliquots of the volume necessary to add to the bay water that was added to the tanks on three days each week (Table 1) and frozen. Later analysis of the frozen sewage showed no appreciable change in its composition over time. The sewage input was maintained for 102 days (4 April-15 July) before it was terminated and the recovery of the systems followed for the next 69 days (16 July-23 Sept.).

\section{RESULTS AND DISCUSSION}

\section{Replication of the microcosms}

For 15 days after the initial intermixing, the 12 tanks remained similar with respect to all of the parameters measured (Figs 2, 3; Table 4). Once the systems were perturbed with sewage, the tanks began to diverge and show the effect of the experimental treatment. However, replication within each treatment remained strong for another 15-20 days. At that point, one replicate in each of the treatments and in the control set began to diverge markedly with respect to ammonia (Fig. 3). The same tanks later developed extremely high nitrate and nitrite levels. It is difficult to account for this anomalous behavior with respect to nitrogen. It apparently had nothing to do

Table 4

Replication of the 12 marine microcosms just prior to the addition of urban sewage. Samples were collected 14 days after intermixing of the microcosm tanks

\begin{tabular}{|lcc|}
\hline Parameters & Mean value & Coefficient of variation $(\%)$ \\
\hline Nutrients $(\mu \mathrm{g}$-at $/ \mathrm{l})$ & & \\
ammonia & 0.15 & 87 \\
nitrate & 0.20 & 60 \\
nitrite & 0 & 14 \\
phosphate & 0.07 & 8 \\
dissolved organic phosphorus & 0.64 & 29 \\
Chl $a(\mu \mathrm{g} / \mathrm{l})$ & 4.08 & 26 \\
Total diatoms (cells $/ \mathrm{ml})$ & 2547 & 93 \\
Total flagellates $(\mathrm{cell} / \mathrm{m} / \mathrm{ml})$ & 74 & 12 \\
Pelagic ATP $(\mu \mathrm{g} / 1)$ & 2.46 & 15 \\
Suspended particles & 290 & 15 \\
$2.8-17.2 \mu \mathrm{m}$ & 2880 & 24 \\
$17.2-39.0 \mu \mathrm{m}$ & 460 & 12 \\
$39.0-50.0 \mu \mathrm{m}$ & 22 & \\
Benthic O2 uptake $\left(\mathrm{mg} / \mathrm{m}^{2} / \mathrm{h}\right)$ & & \\
\hline
\end{tabular}


with the sewage input, since one of the control tanks had the highest nitrogen level. Measurements of the nitrogen fluxes from the benthic boxes were not significantly higher in these tanks. Moreover, the total biomass of infauna present in the sediment ( $\sim 250 \mathrm{mg}$ dry weight) could not have provided enough nitrogen to produce the measured increases even if it had completely decomposed. The same is true of the amount of nitrogen in the pore waters of the sediments. The $\mathrm{C} / \mathrm{N}$ ratio and nitrogen content of the sediments in the anomalous tanks were not significantly different from the other tanks at the end of the experiment. At this point, the source of the additional nitrogen remains unknown. Replication within treatments of the other parameters continued to be adequate to separate the effects of the various sewage levels.

\section{Multivariate analysis of microcosm replication and response}

The long, 170 day time series plots of individual parameters in the microcosms are useful in documenting the behavior of one part of the system and in analyzing the mechanisms that may operate in regulating the structure and function of the community. They also give a simple visual impression of the variation of each parameter within each treatment over time. However, one of the main reasons for using microcosms is to study the response of whole ecosystems rather than their parts. Even with the best reasonably attainable replication, the noise of measurement and sampling errors and the day to day variation of the systems themselves make it almost impossible to use the time series data alone to separate one system or microcosm from

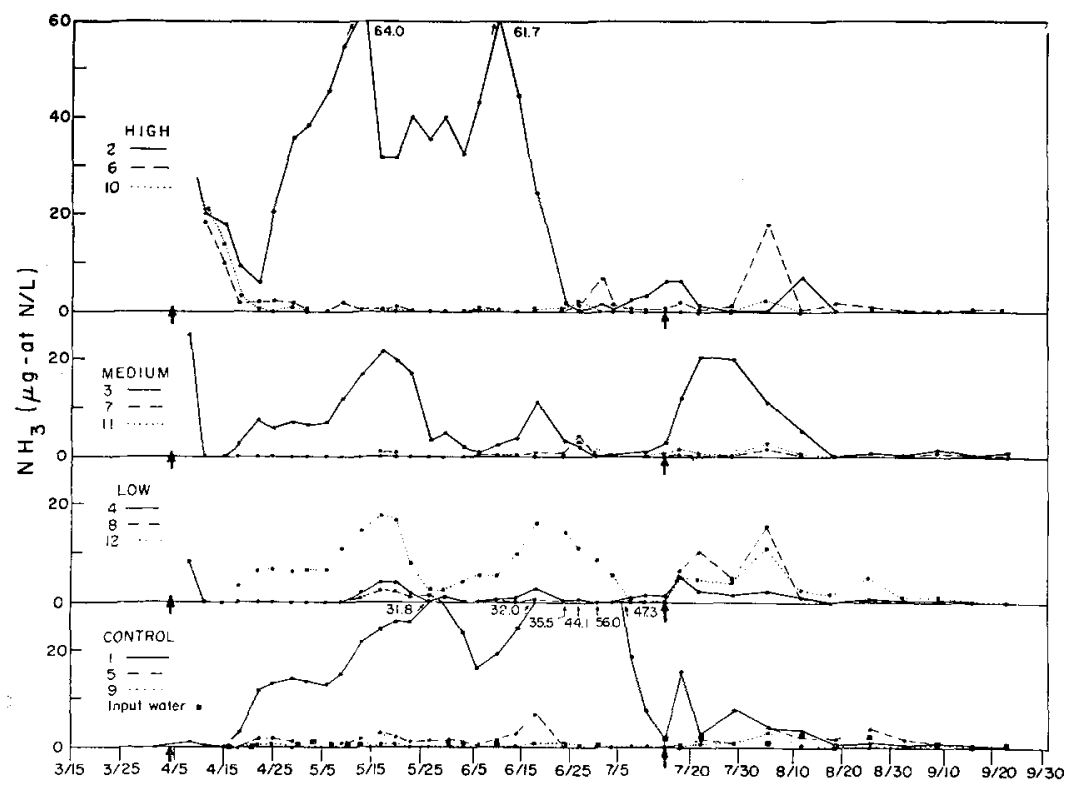

Fig. 3: Concentrations of ammonia in the experimental microcosm, 


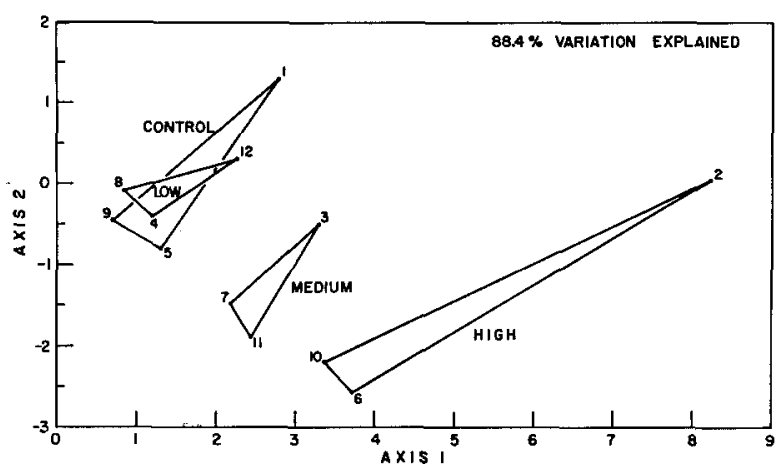

Fig. 4: Canonical variates analysis of pelagic chlorophyll $a$, diatoms, flagellates, pelagic ATP, suspended particles $(2.8 \mu \mathrm{m}, 13.2 \mu \mathrm{m}, 39 \mu \mathrm{m})$ and ammonia in the experimental microcosms during the first month with sewage input. The lines connect replicates within each treatment. The numbers refer to individual microcosms

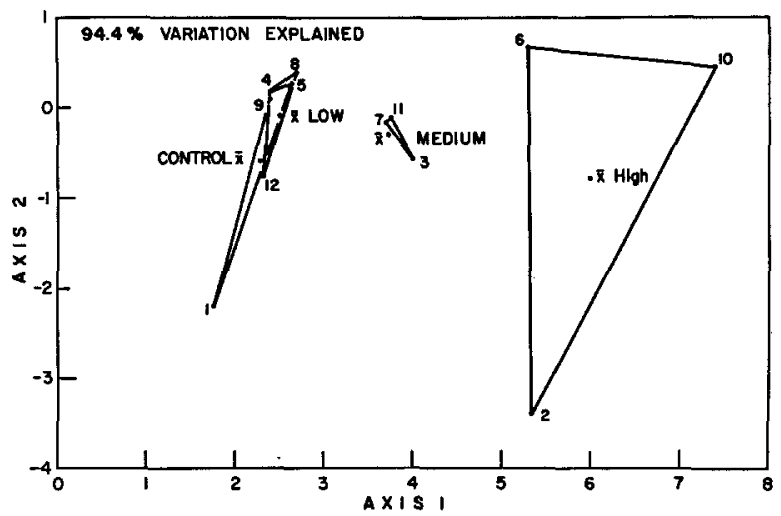

Fig. 5: Canonical variates analysis of chlorophyll $a$ and nutrients in the experimental microcosms during the three month sewage addition. The mean position of each treatment level is shown along with the individual means of each treatment

another or to separate one system in its present state from itself at some other state. Analyses are needed which incorporate a number of parameters simultaneously in arriving at an objective statistical description of ecosystem state or conditions. Our feeling is that a number of multivariate statistical techniques, including canonical variate analysis (Blackith \& Reyment, 1971) and correspondence analysis (David et al., 1973) are especially appropriate for use with experimental ecosystem studies that produce large amounts of data on a large number of parameters. The application of these techniques to ecological data from natural systems has already been described (Chardy et al., 1976).

The relative variation within and among treatments in the microcosms during the first 30 days after sewage additions were begun is clearly evident in a canonical variates analysis of a data set that included ammonia, chlorophyll $a$, numbers of diatoms, numbers of flagellates, pelagic ATP, and the numbers of particles in three 


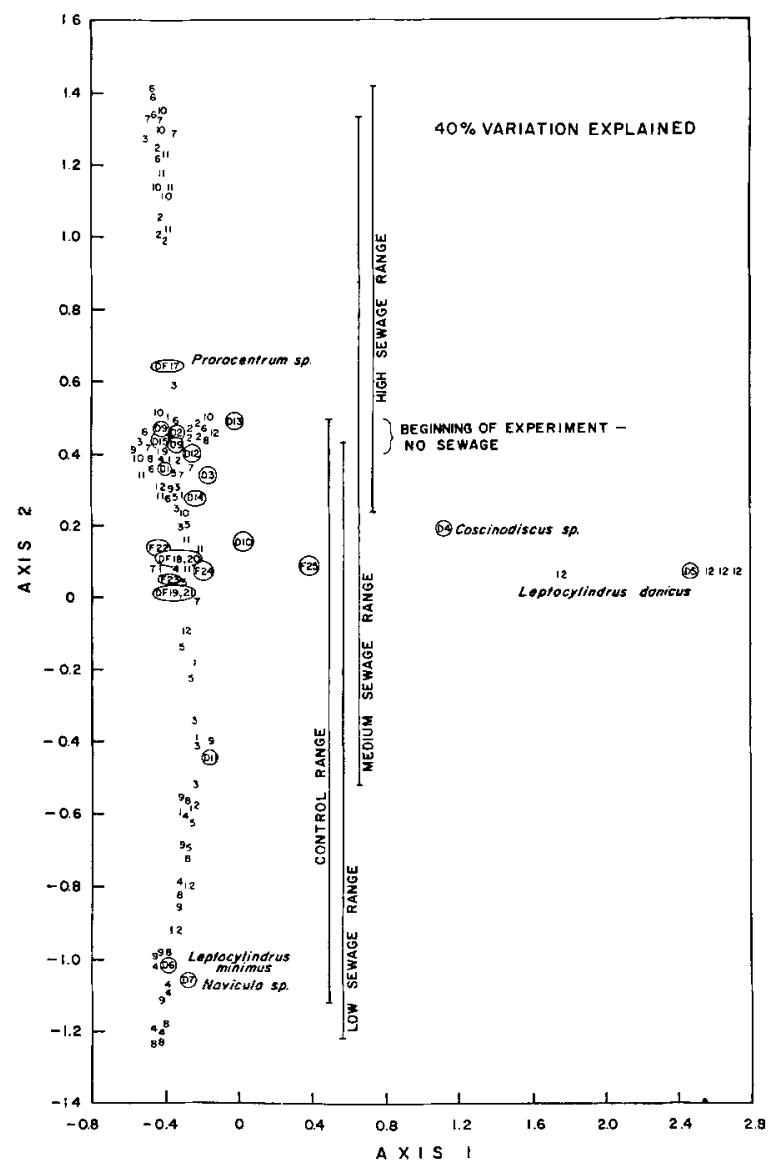

Fig. 6: Correspondence analysis of data on the species composition and abundance of the phytoplankton in the experimental microcosms during the three month addition. Numbers represent samples in individual microcosms while the letters represent particular species of diatoms (D) or dinoflagellates (DF) or flagellates (F) that were associated with the various samples. All of the tanks were similar at the beginning of the experiment before sewage was added (see Fig. 4 for numbers of individual microcosms)

size ranges (Fig. 4). The outlying point in each of the replication triangles represents the individual microcosm in each treatment that developed the anomalous ammonia values discussed earlier. Since the tanks with high nitrogen levels did not appear to differ with respect to any of the other parameters (Fig. 2), it is evident that the multivariate analysis will reflect the extreme behavior of any one parameter. A similar canonical variates analysis on a data set that included all of the nutrients and chlorophyll $a$ from the entire three month period during which the sewage inputs were maintained again showed that the replication remained adequate to show treatment effects along axis one and anomalous ammonia values along axis 2 (Fig. 5).

The data used in canonical variates analysis came from relatively aggregated parameters such as total chlorophyll $a$. Since the treatments could easily be separated 
at this level, it was somewhat surprising to find that variations in the more detailed measurements of phytoplankton species abundance prevented a clear separation of treatment on the basis of the total phytoplankton community structure or on the basis

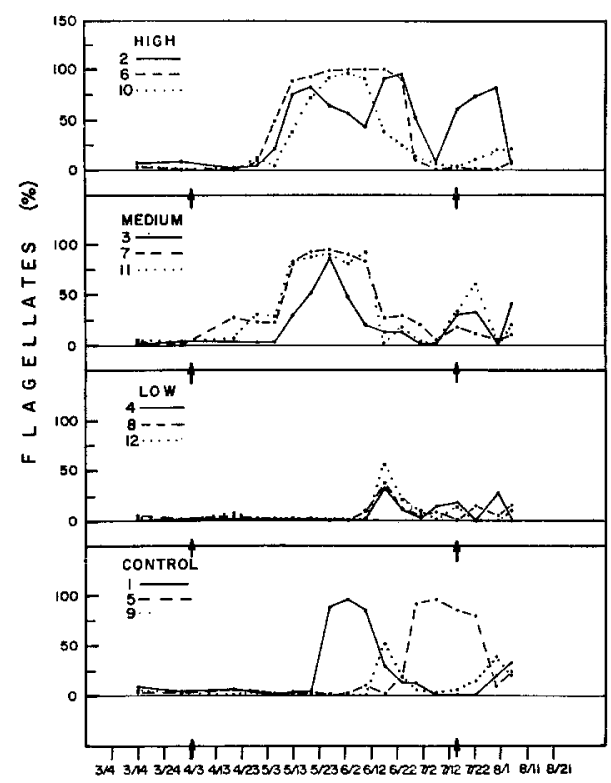

Fig. 7: Contribution of flagellates to the total phytoplankton in the experimental microcosms. Narragansett Bay typically shows a shift from diatoms to flagellates in the summer flora

of "characteristic species" (Fig. 6). The correspondence analysis of taxonomic data did clearly show initial similarity of all of the microcosms. It also reflected some tendency for flagellate groups, especially Prorocentrum, to be more abundant in the higher sewage treatments (Figs. 6 and 7). However, the results suggest that the large amount of effort involved in the taxonomic analysis at lower trophic levels did not provide data that were particularly sensitive to perturbations of this kind. It is not clear whether this result comes about because individual species are relatively insensitive to the perturbation or because the large amount of variation inherent in less aggregated data, including the seasonal change from diatoms to flagellates, makes it more difficult to measure the response of individual species in the context of a total plankton community.

\section{Comparison with the natural system}

One of the prevailing myths in marine ecology is that the goal of microcosm studies is to develop an exact replica in miniature of some particular natural system. Such a goal is neither attainable or necessary. What is desired, however, is to develop a microcosm which is generally similar to the larger system in terms of its trophic structure, the major features of its taxonomic composition, its level of productivity, its rates of material cycling, and in its response to perturbations. The microcosm 
community should also be self-maintaining over a time span that is appropriate for the processes being studied. It is probable that neither the microcosms described here nor those of any other study yet reported have fulfilled all of these criteria. It is hard to know this for sure since, as mentioned earlier, there is no generally agreed upon

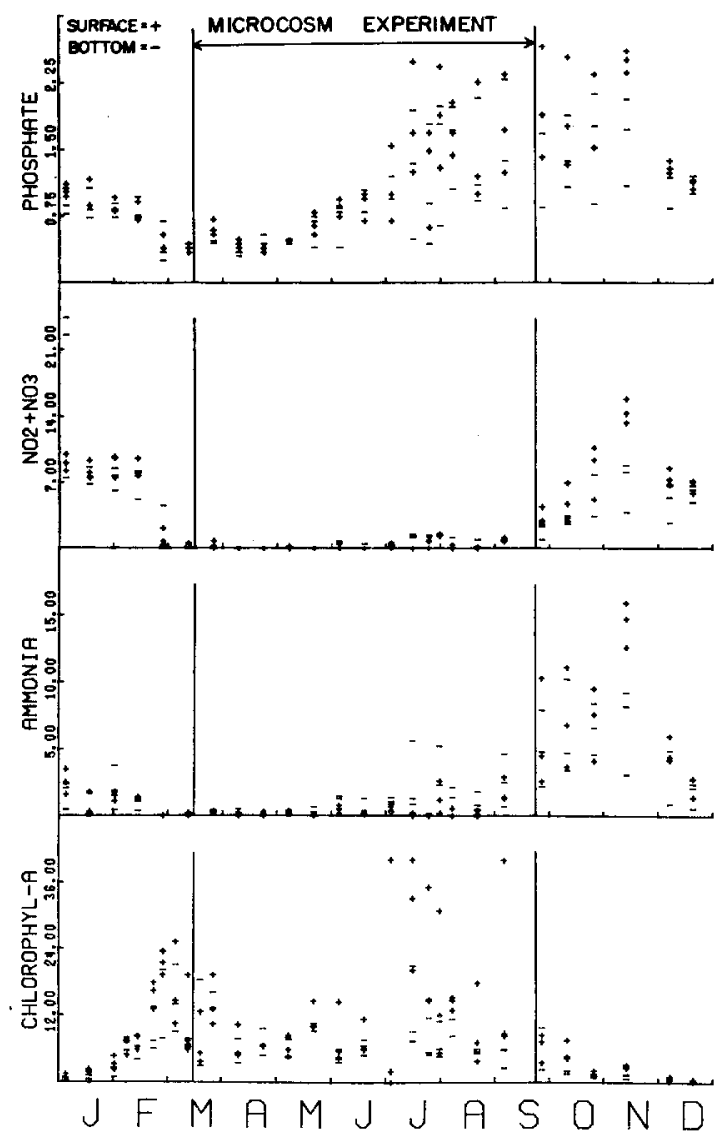

Fig. 8: Range of chlorophyll $a$ and ammonia values found in biweekly samples of surface and bottom water at stations F, G, H in the lower West Passage of Narragansett Bay from August 1971-August 1972 (Fig. 1). The period of microcosm study in 1975 is shown for reference

criteria for the success of microcosms with respect to any of these goals. Nor is it clear that any one of them is of greater or lesser importance than the others for any particular study. It is clear, however, that comparisons of microcosms and natural systems must consider the variation of each. For example, if one compares the time series data from the control microcosms in this study with measurements of the input water collected from the laboratory dock, it appears that there were often appreciable differences (e.g. Figs 2 and 3). However, there is no on e chlorophyll or nutrient value for Narragansett Bay. Instead, there is a range of values that one might normally expect 
to find in different parts of the bay at different times of the year (Fig. 8), and it is against this background of natural variation that the behavior of the microcosm should be evaluated. With the exception of the anomalously high nitrogen levels in one tank, the control microcosms generally fell within the range of values characteristic of the lower West Passage of Narragansett Bay. A canonical variates analysis of nutrient and chlorophyll data from the microcosms and from 13 stations located throughout the bay confirmed this intuitive analysis and indicated that the microcosms responded to sewage inputs by developing characteristics similar to those found along a gradient from the Providence River to the mouth of Narragansett Bay (Fig. 9).

The microcosms remained throughout the study as plankton based systems with grazing food chains containing over 30 forms of phytoplankton and zooplankton. The benthic communities contained a healthy assemblage of macrofauna similar to that

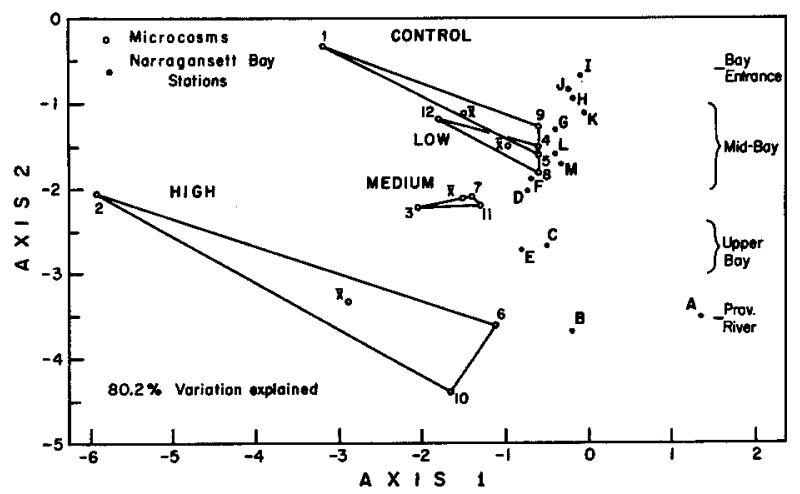

Fig. 9: Canonical variates analysis of chlorophyll and nutrient data from the experimental microcosms and for the same parameters from an annual field study of surface and bottom water at 13 stations in Narragansett Bay. Location of the field stations is shown in Figure 1. Axis 1 portrays the anomalous microcosms, whereas axis 2 gives the eutrophication gradient in the bay and in the microcosms. Over $90 \%$ of all the sewage input to the bay enters in the Providence River. The resulting marked gradient down the bay resembles the gradient developed among the microcosms as a function of sewage input

found in Narragansett Bay. While the benthos was composed of 10 species of macro invertebrates at the beginning of the experiment, the diversity increased through the natural seeding of meroplankton in the input water to 35 species by the end of the study. Benthic biomass increased from 2-4 fold and measurements of oxygen uptake and ammonia flux from the sediment indicated that total benthic metabolism was similar to that found in the bay (Nixon et al., 1976).

\section{Effect of sewage inputs}

The addition of sewage to the microcosms brought about an immediate increase in inorganic and organic nutrients (Fig. 3) which was followed by clear increases in chlorophyll, particulate ATP, suspended particles and cell numbers (Fig. 2). In general, the time series data show higher values and greater variation for all these 
Analysis of marine ecosystems

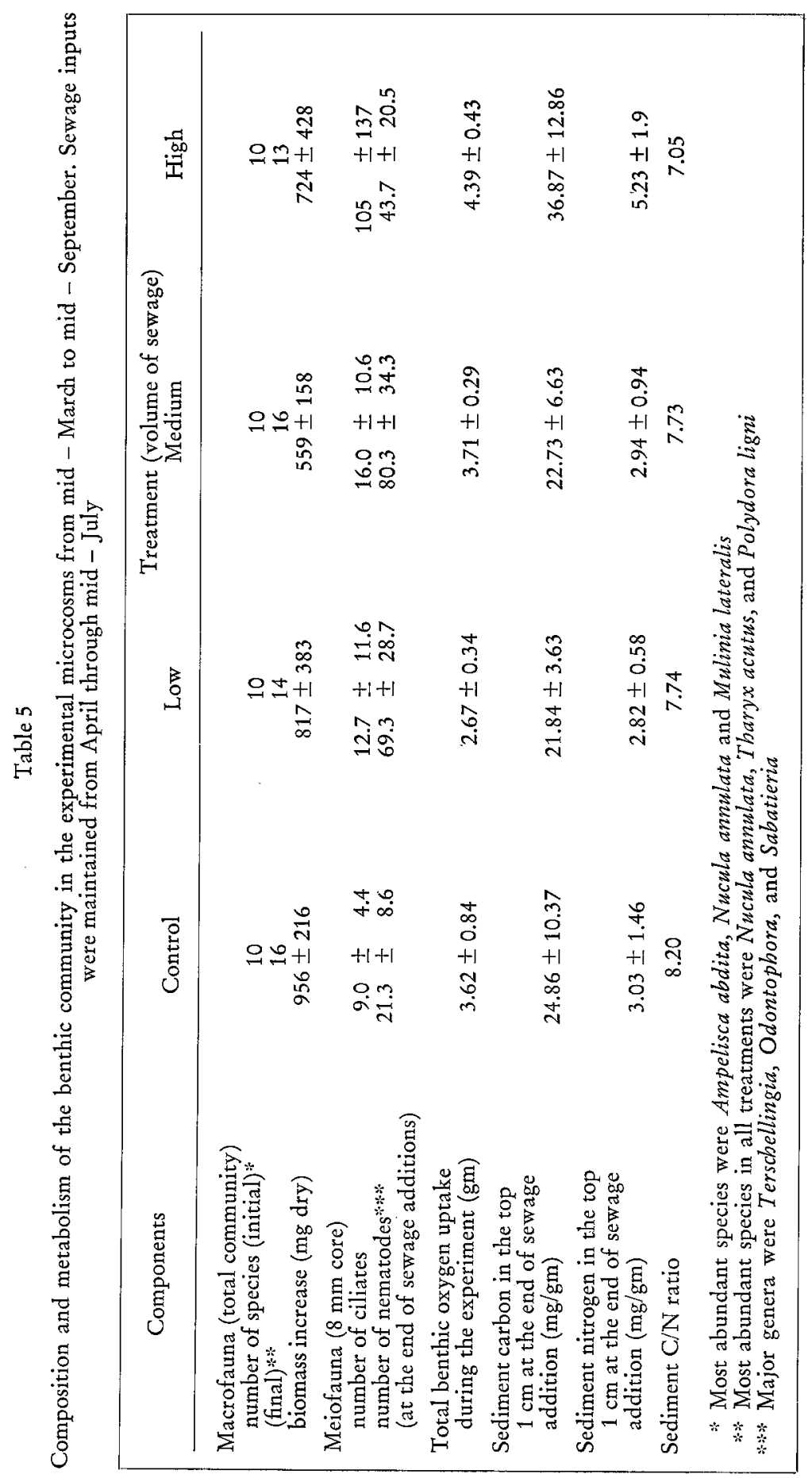


parameters in the microcosms with higher sewage input. There was also a tendency for the phytoplankton in the sewage tanks to contain a larger percentage of flagellates (Fig. 7). However, as shown in Figure 6, changes in the specific taxonomic composition and relative abundance of the plankton as a result of the sewage addition could not be demonstrated with correspondence analysis. The same was true for the taxonomic composition, growth and metabolism of the benthos, where the only statistically significant change appeared to be an increase in the carbon and nitrogen content of the surface sediments in the high sewage microcosms (Table 5).

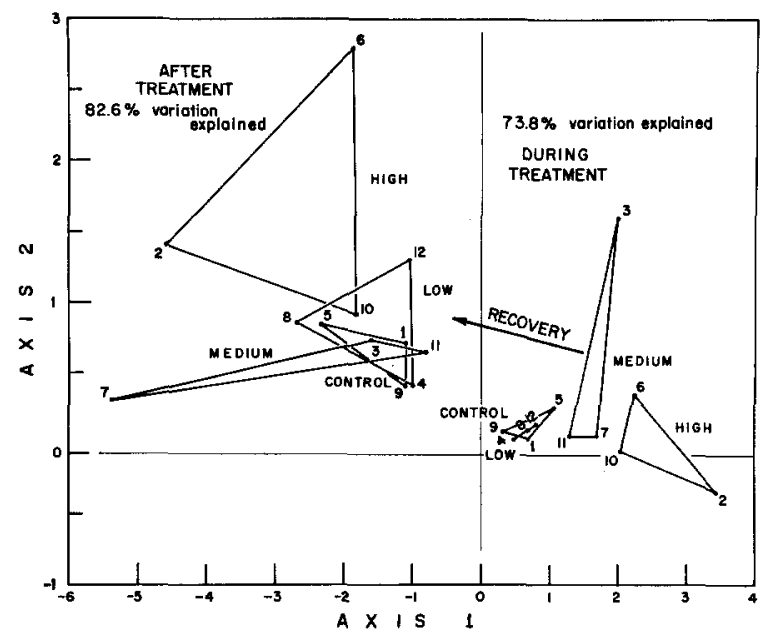

Fig. 10: Canonical variates analysis of chlorophyll $a$, nutrients, pelagic ATP, and particle counts in the experimental microcosms during three months with sewage input compared with the same analysis during the two months following termination of the sewage input. Substantial recovery of lower treatment levels is apparent in overlap of the replication triangles

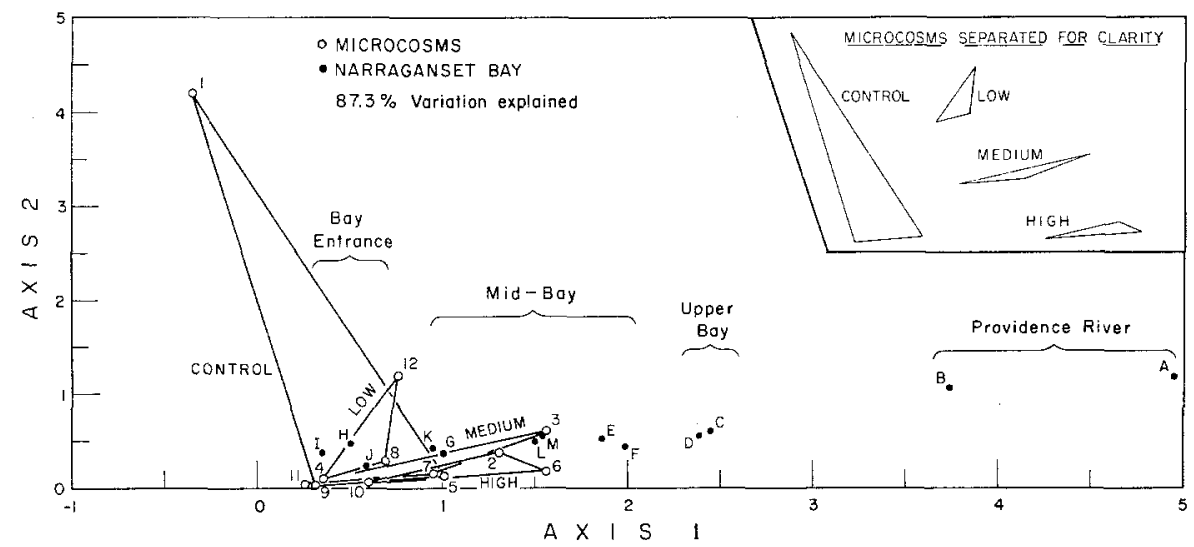

Fig. 11: Canonical variates analysis of chlorophyll, ammonia, nitrate, and nitrite in the microcosms and in Narragansett Bay during the recovery period. Good agreement with lower bay stations is indicated by all treatment levels for this data set 


\section{Recovery}

The time series data show declines in cell counts, chlorophyll, and pelagic ATP that began before the sewage was stopped (Fig. 2). Marked fluctuations in these, and other parameters became particularly apparent and are also characteristic of Narragansett Bay in the warmer months. The high seasonal variability obscures clear trends in the single parameter time series data. However, canonical variates analysis of nutrient values, chlorophyll $a$, pelagic ATP, and particle counts during the three month sewage addition and the two month recovery period did show differences between the sampling periods (Fig. 10). After the sewage was stopped, the replication triangles all began to overlap to some degree, even though seasonal changes had influenced the general condition and variability of all the microcosms. A reduced data set from the microcosms which included chlorophyll, ammonia, nitrate and nitrite was compared with the 13 bay stations during the recovery period using canonical variates analysis (Fig. 11). All treatment microcosms and two controls overlap mid and lower bay stations indicating good recovery for these parameters. Control microcosm 1, by contrast, was positioned high on Axis 2 due to very high values of nitrate and nitrite, apparently derived from earlier high ammonia values. Recovery of the microcosms that had been subjected to the high sewage inputs was still far from complete with respect to all parameters, even though the recovery period was almost twice as long as the flushing time of the systems.

Acknowledgements. We are grateful to Alina Froelich, Betty Buckley, Steve Hale, Jonathan Garber, Jack Kelley, Sybil Seitzinger and to our EPA colleagues Andrea Hurtt, Sue Cheer, Earl Davey and Barbara Guida for help with the extensive laboratory analysis. M. Gayle Kraus performed the meiofaunal analyses. Robert Marrero identified and counted phytoplankton species. Björn Malmgren and Wendell Hahm assisted with the multivariate analyses. This research was supported by a grant from the U.S. Environmental Protection Agency, R-803 143.

\section{LITERATURE CITED}

Abbott, W., 1966. Microcosm studies on estuarine waters. I. The replicability of microcosms. J. War. Pollut. Control Fed. 39, 258-270.

Bertalanffy, L. von, 1968. General system theory. Braziller, New York, 289 pp.

Beyers, R. J., 1963. A characteristic diurnal metabolic pattern in balanced microcosms. Publs Inst. mar. Sci. Univ. Texas 9, 19-27.

Blackith, R. E. \& Reyment, R. A., 1971. Multivariate morphometrics. Acad. Press, London, $412 \mathrm{pp}$.

Bodungen, B. von, von Brockel, K., Smetacek, V. \& Zeitzschel, B., 1976. The planktontower. I. A structure to study water/sediment interactions in enclosed water columns. Mar. Biol. 34, 369-373.

Chardy, P., Glemarec, M. \& Laurec, A., 1976. Application of inertia methods to benthic marine ecology: practical implications of the basic options. Estuar. coast. mar. Sci. 4, 179-205.

Cheer, S., Gentile, J. H. \& Hegre, C. S., 1974. Improved method for ATP analysis. Analyt. Biochem. 60, 102-114.

Cooke, G. D., 1971. Aquatic laboratory microecosystems and communities. In: The structure and function of freshwater microbial communities. Ed. by J. Cairns. Polytech. Inst., Blackburgh, VA., 47-85.

David, M., Campiglio, C. \& Darling, R., 1974. Progress in R- and Q-mode analysis: correspondence analysis and its application to the study of geological processes. Can. J. Earth Sci. 11, 131-146. 
Davies, J. M., Gamble, J. C. \& Steele, J. H., 1975. Preliminary studies with a large plastic enclosure. In: Estuarine research. Ed. by L. E. Cronin. Acad. Press, New York, 1, 251-264.

Farrington, J. W. \& Quinn, J. G., 1973. Petroleum hydrocarbons and fatty acids in waste water effluents. J. Wat. Pollut. Control Fed. 45, 704-712.

Knauss, J. A., Griffin, J. J., Nixon, S. W., Pilson, M. E. Q. \& Smayda, T. J., 1976. A facility for the experimental analysis of coastal marine ecosystems. Tech. prog. Rep. U.S. envir. Protect. Agency, 124 pp.

Kremer, J. N. \& Nixon, S. W., 1975. An ecological simulation model of Narragansett Bay the plankton community. In: Estuarine Research. Ed. by L. E. Cronin. Acad. Press, New York, 1, 672-690.

Levandowsky, M., 1977. Multispecies cultures and microcosms. In: Marine ecology. Ed. by O. Kinne. Wiley-Interscience, London, 3 (3) 1399-1458.

Likens, G. E., Bormann, F. H., Johnson, N. M., Fisher, D. W. \& Pierce, R. S., 1970. Effects of forest cutting and herbicide treatment on nutrient budgets in the Hubbard Brook watershed ecosystems. Ecol. Monogr. 40, 23-47.

Mann, K. H., 1972. The analysis of aquatic ecosystems. In: Essays in hydrobiology. Ed. by R. B. Clark \& R. J. Wooton. Univ. of Exeter, Exeter, 1-14.

- 1975. Relationship between morphometry and biological functioning in three coastal inlets of Nova Scotia. In: Estuarine Research. Ed. by L. E. Cronin. Acad. Press, New York, 1, 634-644.

Menzel, D. W. \& Corwin, N., 1965. The measurement of total phosphorus in seawater based on the liberation of organically bound fractions by persulfate oxidation. Limnol. Oceanogr. 10, 280-282.

Nixon, S. W., Oviatt, C. A. \& Hale, S. S., 1976. Nitrogen regeneration and metabolism of coastal marine bottom communities. In: The role of terrestrial and aquatic organisms in decomposition processes. Ed. by J. M. Anderson \& A. Macfaden. The 17 th symposium of the British Ecological Society. Blackwell, Oxford, 269-283.

Odum, H. T. (Ed.), 1970. A tropical rain forest, a study of irradiation and ecology at El Verde, Puerto Rico. Div. Tech. Inf., U.S. Atomic Energys Commn, 9 chapters.

- 1971. Environment, power and society. Wiley-Interscience, New York, 331 pp.

Patten, B. C., 1971. Coda. In: Systems analysis and simulation in ecology. Ed. by B. C. Patten. Acad. Press, New York, 1, 583-584.

Perez, K., Morrison, G., Oviatt, C., Nixon, S. \& Buckley, B., 1976. The importance of physical and biotic scaling to the experimental simulation of a coastal marine ecosystem. Helgoländer wiss. Meeresunters. 30, 144-162.

Smetacek, V., Bodungen, B. von, Brockel, K. von \& Zeitzschel, B., 1976. The planktontower. II. Release of nutrients from sediments due to changes in the density of bottom water. Mar. Biol. 34, 373-378.

Solorzano, L., 1969. Determination of ammonia in natural waters by the phenolhypochlorite methods. Limnol. Oceanogr. 14, 799-801.

Steele, J. H., 1974. The structure of marine ecosystems. Blackwell, Oxford, 128 pp.

Strickland, J. D. H. \& Parsons, T. R., 1968. A practical handbook of seawater analysis. Bull. Fish. Res. Bd Can. 167, 1-311.

Takahaski, M., Thomas, W. H., Siebert, D. L. R., Beers, J., Koeller, P. \& Parsons, T. R. 1975. The replication of biological events in enclosed water columns. Arch. Hydrobiol. 76, 5-23.

U.S. Army Corps of Engineers, 1959. Contamination dispersion in estuaries, Narrangansett Bay. Hydraulic Model Investigation. Misc. Pap. U.S. Army Eng. Waterways Exp. Stn 2, $1-332$.

Walsh, J. J., 1975. A spatial simulation model of the Peruvian upwelling ecosystem. Deep Sea Res. 22, 201-236.

First author's address: Candace A. Oviatt

Graduate School of Oceanography

University of Rhode Island

Kingston, Rhode Island O2881

USA 